\title{
"Transmission at generation": Could original sin have happened at the time when Homo sapiens already had a large population size?
}

\author{
ANTOINE SUAREZ \\ Center for Quantum Philosophy, Zürich \\ suarez@leman.ch
}

\begin{abstract}
Models have been proposed assuming that God created the first human persons at the time when Homo sapiens already had a large population size; this hypothesis agrees with emerging data of evolutionary genetics. The present article argues that in such a historical context the propagation of original sin can be explained through "transmission at generation", in accord with Romans 11:32, and the "Decree concerning original sin of the Council of Trent".
\end{abstract}

Keywords: human evolution; God's intervention; first human persons; Adam and Eve; moral responsibility; original sin; "Relational damage"; "Transmission at generation"; atonement; Romans 11:32; Darwinian principles; “monogenism”; “polygenism”.

\section{Introduction}

Emerging results in evolutionary genetics support the hypothesis that humanity could not have had only two genetic ancestors at any time in the last several hundred thousand years (Li and Durbin 2011, Scally and Durbin 2012, Qiaomei et al. 2014, Coyne 2014). According to the geneticist Richard Durbin, "any attempt to separate all the DNA in humans from that in ani- 
mals passes through many individuals. Only if we select a small fraction of the genome can we discuss a monogenic origin"; and any attempt to reach such an origin will include archaic hominins with whom we share multiple common ancestors, if not the extant apes (Driessen 2015).

These scientific results have stimulated the search for explanations assuming that God created the first human persons at the time when the species Homo sapiens already had a large population size.

In this line of thinking we have recently proposed the "Moral and legal responsibility" model: "The key idea allowing us to establish when God's intervention occurred to create the first human persons is the tenet that these were aware of their moral and legal responsibility" (Suarez 2015).

On one hand, the "Moral and legal responsibility" model is rather obvious from the point of view of the Christian teaching about original sin: The first persons would not have been able to sin if they had not been conscious of the own freedom and moral responsibility. It is noteworthy that the phrase "good and evil" used in (Genesis 2:9) to describe God's commandment, was also used in legal contexts to describe "legal responsibility" (Clark 1969).

On the other hand, the model fits well to the disappearance of intermediate varieties by natural selection (Darwin $1859, \mathrm{X}$ ): This evolutionary fact produced the sharp separation of species to the end of delimiting humanity from the other extant forms of life: If all the extinct ancestors were still alive, then there would be a complete continuum of "bodies" filling the gaps between humans and other mammals (Dawkins 2012a). The ascription of "human rights" would be a question of arbitrary decision, and racism would become predominant. The disappearance of "intermediate forms" is highly useful to the end of founding a coherent human legal order. "Darwinian evolution" makes sense as preparation to "moral evolution".

Accordingly, clear signs to ascertain when the first human persons appeared are achievements that reveal rational personhood with awareness of moral and legal responsibility. These achievements can undoubtedly be found at the origin of the civilizations when the Neolithic Revolution reached its culmination around $3500 \mathrm{Bc}$. Therefore we assume that the first 
human persons were created at the dawn of civilization, and this means when the total Earth Homo sapiens' population is estimated in several millions of individuals (McEvedy and Jones 1978).

This article aims to explore whether the assumption of such a large population is compatible with the Catholic teaching about the creation of human persons and propagation of original sin.

The perspective we take is not that of deducing how original sin is transmitted from "Adam and Eve" but how the first human persons were created, starting from original sin and Redemption. Our main assumption is the characterization given by St. Paul in Romans 5:12, 14, 17-19, and the principle stated in Romans 11:32. In accord with the Council of Trent we accept that original sin is a state which proceeds from the first sin, and is "transmitted by propagation and not by imitation" to all human persons since the first trespass, so that "the state of original sin is in everyone as his own" (Council of Trent 1546, and Catechism of the Catholic Church 1993, Nr. 404).

In this sense we agree with Augustine of Hippo's tenet that original sin cannot be reduced to a bad example set by the first man (Adam) (Augustine 412). Recent research seems to support the thesis that even St. Augustine deduced the theology of original sin from the theology of Redemption, and not the other way around, as it is often assumed (O'Callaghan 2014). Nonetheless we do not share the view that original sin is transmitted from Adam to all men only by "natural descent", if by this expression one means that Adam is the common genetic ancestor of all human persons.

Notice that the estimate of $3500 \mathrm{BC}$ for the time of creation of the first human persons fits rather well to the number of 76 generations from Adam to Jesus given by the Gospel of Luke (3:23-38). If one alternatively assumes that the first persons were created at the time of first burials (100'000 BP: Qafzeh) or cave paintings (40’000 вр: Lascaux, Altamira, Maros-Pangkep), and considers that at this time there were different varieties of Homo which are supposed to have reproduced with each other (Early Modern Humans, Neanderthals, Denisovans, Flores Man) the corresponding population may have ranged in tens or hundreds of thousands. So this difference does not matter for the question we are addressing. 


\section{How did God create the first human persons?}

The assumption that the first human persons appeared within a large population of Homo sapiens implies that God transformed existing adult human animals into human persons. In this Section we tackle the question about how this transformation was done.

In accord with Thomas Aquinas' hypothesis of "successive ensoulment" we assume that God transforms the human animals into morally human persons by substituting the "animal life-principle" with a "spiritual rational soul".

In terms of the philosophy of Aristotle and Thomas Aquinas this assumption means that each of these modern humans underwent a substantial transformation from a non-personal human animal to a personal human being (Suarez 2015). Thomas Aquinas assumes a similar transition from an animal to a personal human being when he explains the ensoulment of the embryo by means of "delayed hominization" in the Summa theologica (S.th. I, q. 76, a. 3, Reply to Objection 3; q. 118, a. 2, Reply to Objection 2). It has been shown that this hypothesis is untenable in the context the human embryo, not only because this hypothesis is based on old-fashioned science but mainly because it is a philosophical inaccuracy (Suarez 2011). The reason is (as we will see at the end of this Section) that "successive animation" is incompatible with acknowledging interpersonal relationship, and therefore has to be excluded for founding morality and law coherently. By contrast nothing speaks against the assumption that God created the first human persons by replacing the "animal souls" of adult animals with "human spiritual rational souls".

However we definitely exclude a dualistic reading of the tenet that "the spiritual soul is the form of the human body". The human person is not a composite of soul and body; the soul forms the body by animating the organic stuff ("the dust of the land" in Genesis 2:7): The body is not the receptacle of the soul but the soul itself appearing in the space-time (Suarez 2015, Appendix 1).

This non-dualistic concept of soul is perfectly compatible with both neuroscience and quantum physics. In many respects (for instance to de- 
fine personal identity) it is advantageous to rely on the concept of human personhood inspired in the teaching about the triune God, however such a concept is perfectly compatible with the concept of the 'soul'. What is more, the concept of 'human soul' may be especially helpful for coherently explaining that Jesus Christ has a true human body and truly died, although he is a divine person. Highly interesting is the remark by Joel Green that after the resurrection the corporal appearance of Jesus Christ is not the effect of a vision, in contrast for instance to the appearance of the angel Raphael in the book Tobit (Green 2004, 91-100). If one tries to substitute the operations of Christ's human soul (knowledge and will) through those of His divine person one falls into the heretical position of Apollinaris of Laodicea. When a mother or a father speak and play with a baby they adapt their mental capabilities to the baby stage and even behave like a baby. One could say that they assume a 'baby's soul' and become a baby, without ceasing to be an adult person. Similarly God's Son restricted their divine pure spiritual capabilities to that of a human person, that is, He assumed a 'human soul' to become an embodied divine person.

In this respect Benjamin Libet's experiments are relevant as well, since they may be considered to demonstrate unconscious although voluntary movements (Adams and Suarez 2013, 282-284). This unconscious spiritual activity distinguishes the human person from pure spiritual persons like God and the angels. If human persons were conscious all the time (without need of sleep) then the concept of a human soul might be redundant, but then the human person would be an angelic person. In other words, pure spirits are persons who have neither soul nor body; by contrast, human persons whose consciousness is intermittent (mainly limited by sleep) have a soul and are embodied consciousness or personal bodies.

Lawson Stone expresses the dream of overcoming "a dualistic reading of human nature" as "matter" and "spirit", and asks: "What if, for example, quantum physics is correct, and there is no final distinction between matter and energy? What if, in the end, materialism is just as naive and uninformed as idealism?” (Stone 2004, 61). The view I am proposing supports Stone's dream and even goes beyond it: Quantum experiments tell us 
that even the "conservation of energy", the most fundamental rule in the "material world", is underpinned by non-material agency, and even spacetime emerges from outside space-time (Suarez 2013a).

For Christian theology, all that is "natural" is ordained and sustained by God. Therefore the proposal that God "infused" or "invested" "the spiritual capabilities", or "intervened" to grant them, should not be understood in the sense that "natural" is distinct from "what God does". Thus the "divine intervention" transforming an individual of the species Homo sapiens into a human person means that God assigned part of the government of the brain to a new person different from a pure spirit.

In this sense one can say that "true (personal) humanness" is developed through natural (God-given) processes, so that each new personal member of Homo sapiens was biologically identical to his non-personal precursor. The discontinuity happened at the spiritual level. At the appearance of the first human persons, God intervened naturally but differently from what He did at the creation of non-personal animals. In the former case personal living beings appeared that in principle were morally responsible for their actions, whereas in the latter case living beings appeared without any moral responsibility.

Would it have been possible for personal modern humans to have met non-personal ones and lived with them? I think the answer is no. The reason is that spiritual capabilities (consciousness, free-will) are not directly accessible to the senses and can be ascertained only through the directly observable human body. The neurophysiological discovery of mirror neurons shows that "I experience directly only my own consciousness and free will”, and access these capabilities in other humans "through first-person knowledge” (Fogassi and Rizzolatti 2013, 117). I conclude that the human being in front of me also shares these valuable capabilities because: (a) they have the same specific body as me, and (b) this body exhibits the same movements that I make when expressing my thoughts, emotions, and claims for rights (so called "spontaneous movements") (Adams and Suarez 2013, 283). This means that the "spontaneous movements" exhibited by bodies of the species Homo sapiens are the observable basis of any consistent moral and legal order. 
Therefore we accept the following crucial principle:

After the appearance of the primal human persons by God's intervention, the basis of any consistent moral and legal order is that every animal of Homo sapiens is recognized as a person worthy of respect. (Suarez 2015, 76).

Knowing other human persons involves the wish that they respect my body and my commitment to respect their bodies. In other words, knowing "what is" requires claims about what "ought to be". The distinction between human animal and human person is fitting to explain the creation of the first human persons, but such a distinction is no longer fitting in the context of law, at a time when the right to personal identity holds. Once the first persons appeared, the human animal becomes the observable basis of any consistent legal order: Every human animal ought to be recognized as a person worthy of respect at each stage of development. Thomas Aquinas' and Aristotle's explanation of the embryo ensoulment by successive animation rests on the assumption that there can be a human animal that is not a human person within a community of human persons. As said, such an assumption is a philosophical mistake (Suarez 2011, 177-178).

We exclude the coexistence of personal and non-personal individuals of Homo sapiens, and this implies that the mere presence of a personal modern human, would have transformed a non-personal human (an animal) into a person. In this sense one can distinguish between a "biological" and a "personal" species of Homo sapiens. However individuals of these "two species" did not live together and reproduce with each other at any time.

Richard Dawkins himself claims:

We should not live by Darwinian principles [...] one of the reasons for learning about Darwinian evolution is as an object lesson in how not to set up our values and social lives.

[...] you are right when you say that aspects of what Hitler tried to do could be regarded as arising out of Darwinian natural selection. That's exactly why I said that I despise Darwinian natural selection as a motto for how we should live. [...] 
I very much hope that we don't revert to the idea of survival of the fittest in planning our politics and our values and our way of life. (Dawkins 2012b).

That is to say that the principles by which we should live cannot come from evolution but must be derived from elsewhere. Thus Dawkins' reasoning seems to strengthen Immanuel Kant's moral proof for the existence of God after all.

In summary, life evolved gradually by incredibly tiny leaps and amazing disappearance of intermediate varieties into the sharply forms of life we know today. Then a "leap" happened at the spiritual level: God transformed the animals of Homo sapiens into persons. Before this "leap" it does not make sense to speak about "the very first human being". Ascertaining when the primeval human persons were created does not require any observable “biological discontinuity” (Lorda 2015, 179), but observable cultural achievements (civilisation). By contrast ascertaining the beginning of a new personal identity amidst a community of persons requires a sharp biological discontinuity (fertilization or something equivalent). Notice to finish this Section that the "transformation of non-personal individuals into persons" can be considered a form of generation of persons. This will be relevant later to explaining the transmission of original sin.

\section{The original sin in the light of Thomas Aquinas' Summa theologica}

What does 'original sin' mean in the context of the preceding Section? In the Summa theologica Thomas Aquinas discusses a couple of questions that are significant in this respect: Thomas definitely states that in the state of innocence, there would have been generation, and this would have happened through coition just like now. Adam and Eve would have generated children even if they had not sinned and kept the state of innocence. As reason he astonishingly points out that:

there would have been generation of offspring for the multiplication of the human race; otherwise man's sin would have been very necessary, for such a great 
blessing to be its result. [...] Although generation in the state of innocence might not have been required for the preservation of the species [because in the state of innocence man would have lived for ever], yet it would have been required for the multiplication of the individual. (S.th. I, q. 98, a. 1 ; italic by us).

Subsequently Thomas states that in the state of innocence Adam's and Eve's children would have been born without original sin since "the children would have been assimilated to their parents as regards original righteousness" (S.th. I, q. 100, a. 1).

Finally, Thomas states that, although born without original sin, such children would have been capable of sinning, or in other words "they would not have been born confirmed in righteousness” (S.th. I, q. 100, a. 2).

This analysis has an important implication: Even if Humanity is descended from a single couple (Adam and Eve), generations may have passed before the appearance of sin, and hence there is no requirement that the “originating original sin" (peccatum originale originans) was committed by a single pair from which every human person is biologically descended. Or in other words, whether the first sinners were or were not the genetically common ancestors of all human persons is irrelevant for belief in the original sin.

This means that Thomas considers it possible that, in the beginning, humanity could have consisted of two groups: one of people in the state of innocence and one of people who fell and lost this state. However Thomas does not address (at least in the Summa theologica and to my knowledge nowhere else) the question of how such a population evolved in the following course of history.

In my view this question deserves to be discussed for it may help to illuminate the mystery of the "originated original sin". We do this in the following Section 3.

\section{St. Paul's Romans 11:32}

To answer “the question that Thomas didn't address” we invoke the principle St. Paul enounces in Romans 11:32: “For God has bound everyone over to disobedience so that he may have mercy on them all." 
With relation to our question this statement by St. Paul means that God has bound everyone over to the "state of original sin" so that he may redeem them all.

The main tenet of the Christian faith is that people, who are in a state of sin, and in particular original sin, need Redemption to receive eternal life. By contrast, people in the state of original righteousness would not need such Redemption. But maintaining people in a state of righteousness together with people in a state of sin would not be suitable for the sake of Redemption. Although intuitively this assertion may seem obvious, it deserves closer attention. For the scope of this article we advance an argument in five points that may stimulate further work:

1) The essence of sin is a delusion: In face of God's grandeur and power the sinner wants "to be like God" considering this equality something to be used to his own advantage, and overlooking that God is love (1 John 4: 8). The sinner tries to give himself everlasting happiness without God's help. In case of the fallen angels the consequence was immediate damnation: Because of their superior intelligence and will, once they sinned God could not move them to repent without destroying their free will. By contrast in case of men God found a way for converting them without abolishing their freedom:

He made himself nothing by taking the very nature of a servant $[\ldots]$ He humbled himself - by becoming obedient to death - even death on a cross! (Philippians 2:5-9).

In a sense one could say that God "learned" from the bad experience with the fall of angels and humans, and decided to hide completely His majesty and power in the cross so that we can see His true essence: love. By dying in the cross God shows us the right way to become like Him: Transforming suffering into love.

2) C. S. Lewis has written brilliants pages arguing that pain is a necessary way to break the "selfish will" and move the sinner to convert again to God (Lewis 1940, VI). Pain is a consequence of God's mer- 
cifulness and definite will for redeeming the human sinners; pain appears as an essential ingredient of God's Redemption plan: it is the price to pay for having conversion with freedom.

3) Pope Emeritus Benedict XVI has recently expressed a similar idea: "God simply cannot leave 'as is' the mass of evil that comes from the freedom that he himself has granted." The true overcoming of evil can ultimately be realized only in the suffering of love. The crucified and risen Christ is the power that can counter the power of evil. On this basis we can even understand the meaning of our own sufferings as inserted into the suffering love of Christ and included as part of the redemptive power of such love. (Benedict XVI 2016).

4) People in the "state of innocence" would have shared the gift of impassibility, i.e.: immunity from suffering. If suffering love is the way for conversion in freedom, maintaining people in the state of innocence among the sinners would have been nonsensical on the part of God. This conclusion is also supported by the fact that those who become baptized and get rid of original sin they remain subject to suffering, aging and death.

5) One could also argue that those who kept the state of innocence neither would have been able of redeeming the fallen, since this required an explicit divine intervention (as in the Incarnation), nor necessary for the "great blessing" of multiplying the human kind, since this could have been done by the fallen as well. Hence, the presence of people in the state of innocence among the sinners would also have been useless.

Accordingly we accept that after the first humans sinned, God's plan for Redemption requires that any new human person is created in the state of non-innocence.

This analysis fits also well with the Easter Liturgy calling the Original sin "truly necessary sin" and "felix culpa": Felix was not the actual misdeed of the first human sinners but the decision of God to create their descend- 
ants without the state of innocence, in order to make it possible to redeem sinners of all times. In order to avoid misunderstandings in this context, it is worth clarifying that God was entirely free to create humankind or not, and after the fall God remained entirely free to redeem human beings or not. However, once God decided for Redemption He was no longer free to maintain people in the state of original righteousness along with people who had lost this state. This seems to be what St. Paul declares in Romans 11:32: God put His omnipotence and creativity at the service of mercy, and invented an amazing way to bringing good out of sin (Burkhart 2015, 170).

In this perspective the 'fall' bore the state of original sin because it was the first $\sin$ in the history of humanity, and not because it was the sin of the primeval human persons: If the primeval persons sinned, their sin bore the state of original sin; if generations passed before the first sin arrived, then this first sin was the 'fall' and bore the state of original sin even if it was not committed by the primeval human persons. The state of original sin is a product of both the pride of the first sinners and God's will to redeem sinners. Thus 'Adam' is the symbol of the first sinner, who transgressed as if all people were subsumed into him. As soon as the first sin happened, in order to make it possible to redeem the sinners, God acted as if all humanity was in the state of sin and needed Redemption.

This conclusion fits with St. Paul's claim in Romans (5:19) that "through the disobedience of the one man the many were made sinners". Thus the 'fall' is both a historical event involving a couple or community, and the common experience of all humanity (Rom 3:23, 5:12, 11:32). In this respect I share George Murphy's appraisal: "if we take the idea of inspiration of Scripture seriously, it is not hard to believe that Paul could have been led to a deeper understanding than that of the earlier biblical author" (Murphy 2006). Note however that the expression "because all sinned" (Romans 5:12) should not be interpreted in the sense that each (past, present, and future) human person actually sins, and only at this moment enters the state of sin and has need of Redemption, because this would amount to claim that human persons cannot freely decide to sin or not to sin. Accordingly, Romans 5:12 and 11:32 seem to support the idea 
that original sin is a state of deficiency, which is transmitted as a consequence of the first sin. This view is apparently supported by Juan Luis Caballero's analysis (Caballero 2014).

This explanation fits also well with other claims by Thomas Aquinas, as for instance that the seat of original sin is not the flesh but the soul. And not only in respect to the soul's power (will, intellect) but infects the very essence of the soul; "the soul is the subject of original sin chiefly in respect of its essence" (S.th. I-IIae, q. 83, a. 2). (As said previously in Section 1 , the concept of 'soul' does not necessarily imply a 'dualistic' view of human nature).

Against the interpretation of Romans 11: 32 we are proposing one could object that it leads to consider that God is the cause of the original sin:

We answer that any act requires God's cooperation; otherwise the act could not take place (every action of a creature is brought into existence and sustained by God). God cannot withdraw his cooperation because this would contradict his decision to create man free. Nonetheless "He [God] is not the cause of sin, because he does not cause the act to have a defect" (S.th. I-IIae, q. 79, a. 2). One could say that God acts like a pianist playing the melodies he wants; however, at intervals, God accepts to play what a human person wants. It is God who works in us, both to will and to work, but He is not the author of the sin in us. Similarly, mankind's first fall "bounds" God (because of His mercy) to create human persons in the state of original sin, that is, lacking the state of innocence. But the reason that God has acted this way is not His will, but the humans who fell (Suarez 2015).

The very malice of sin is that the sinner leads God to do something against His will, in the same way that the "prodigal son" (Luke 15:11-32) "obliges" his father to give him his share of the estate because the father respects the son's freedom. This malice was uppermost in the case of the first sin: God was bound to create human persons in a state of non-innocence, and thus act against His first will, not only as the cause of a singular sinful act, but every time He creates a new human person. Nonetheless in creating human persons in the state of non-innocence God makes it 
possible for them to be redeemed, and in this sense the state of original sin is a consequence of God's mercy and love: "Where sin abounded, grace abounded much more" (Romans 5:20).

Additionally one can say with Thomas Aquinas:

The corruption of original sin is nowise caused by God, but by the sin alone of our first parent through carnal generation. And so, since creation implies a relation in the soul to God alone, it cannot be said that the soul is tainted through being created. On the other hand, infusion implies relation both to God infusing and to the flesh into which the soul is infused. And so, with regard to God infusing, it cannot be said that the soul is stained through being infused; but only with regard to the body into which it is infused. (I-IIae, q. 83, a. 1, Reply to Objection 4).

In other words, the original sin affects the whole of human nature, not like some genetic illness, but as a deficiency in the soul with relation to its unity with the flesh. Since this state belongs to the soul's essence (for it is created with the aim of building a human body), the insubordination of "concupiscence" to reason happens at the very moment of each soul's creation (i.e. the conception of each human person) and induces the contradictory urge to search temporal contentment, despising eternal joy, the inclination to reach happiness by oneself without God's grace. (In Section 5 we argue that "concupiscence" may relate to the selfish Darwinian propensities).

On the other hand, the view we are proposing on the basis of Romans $11: 32$ avoids oddities that arise if one puts the accent on the biological function and ties the original sin to the very act of seminal generation, as Thomas Aquinas does in certain questions in line with Augustine of Hippo (I-IIae, q. 81, a. 4, On the contrary). So for instance Thomas reaches the conclusion that the original sin is transmitted only by the father, to the extent that if Eve, and not Adam, had sinned, their children would not have contracted original sin, whereas if Adam, and not Eve, had sinned, their children would have contracted it (S.th. I-IIae, q. 81, a. 5, Reply to Objection 2). And if someone had been conceived miraculously from hu- 
man flesh would not have the original sin (I-IIae, q. 81, a. 4). This way one can certainly conclude that the flesh Jesus Christ's body consisted of, was not stained by the sin, but one has to conclude too that His mother Mary could not have been conceived immaculate because she was not virginally conceived. Indeed Thomas states that:

According to the Catholic Faith we must firmly believe that, Christ alone excepted, all men descended from Adam contract original sin from him. (S.th. I, IIae, q. 81, a. 3)

a sentence that apparently implies that Christ's mother contracted original sin from Adam and, in the light of today's Magisterium, should be considered heretic.

By contrast if one focus on the view that the original sin affects the very essence of the soul (as Thomas himself also states) because for the sake of Redemption God cannot do otherwise than creating the souls lacking the gifts proper to the state of innocence, then it is quite appropriate and convenient that God also for the sake of Redemption provides Mary's soul with such gifts, and it is obvious that Christ's body was not stained with the original sin.

In summary, according to Romans 11:32 for the sake of Redemption after the fall only people without the state of innocence and necessitating Redemption remained in this world.

\section{Two models: "Relational damage" and "Transmission at generation"}

If the original sin was not necessarily the sin of two persons who are genetically the common ancestors of all human persons, then nothing speaks against assuming that God created the first human persons at the time when Homo sapiens had a rather large population size. But how does sin propagate in order that on Earth only people in need of Redemption remain? 
In the following we discuss two possible answers and compare them to the teaching of the Council of Trent.

\subsection{Propagation through "relational damage"}

The explanation of original sin as "Relational damage" was proposed by Cardinal Joseph Ratzinger in four homilies the author held during Lent 1981, at Liebfrauen-Dom in Münich. These homilies appeared in 1986 as a booklet, which may be considered the first published Ratzinger's attempt to reformulate Catholic teaching on this matter. Nonetheless Ratzinger seems to have taught these ideas as early as 1964 in lectures he imparted in Münster (Sanz 2014). The 1986 booklet was reedited in 1996 and 2014. In our following analysis we will mainly refer to Chapter 3 about Original sin ("Erbsünde") in the Fourth Homily. The corresponding text is reproduced by "Institut Papst Benedikt XVI" quoting the first edition of 1986, and remains unchanged in the 2014 edition, which appears under the author's name "Joseph Ratzinger/ Benedikt XVI" (Ratzinger/Benedict XVI 1986; 2014, 72-73). One can therefore safely assume that the text also reflects the author's thinking to date.

Ratzinger's main tenet is that original sin consists in a relational damage affecting every person at the moment he or she begins human existence:

Theology refers to this state of affairs by the certainly misleading and imprecise term "original sin." What does this mean? Nothing seems to us today to be stranger or, indeed, more absurd than to insist upon original sin, since, according to our way of thinking, guilt can only be something very personal, and since God does not run a concentration camp, in which one's relatives are imprisoned, because he is a liberating God of love, who calls each one by name. What does original sin mean, then, when we interpret it correctly? Finding an answer to this requires nothing less than trying to understand the human person better [...] Human beings are relational, and they possess their lives themselves- only by way of relationship. I alone am not myself, but only in and with you am I myself. To be truly a human being means to be related in love, to 
be of and for. But sin means the damaging or the destruction of relationality. Sin is a rejection of relationality because it wants to make the human being a god. Sin is loss of relationship, disturbance of relationship, and therefore it is not restricted to the individual. When I destroy a relationship, then this event -sin- touches the other person involved in the relationship. Consequently sin is always an offense that touches others, that alters the world and damages it. To the extent that this is true, when the network of human relationships is damaged from the very beginning, then every human being enters into a world that is marked by relational damage. At the very moment that a person begins human existence, which is a good, he or she is confronted by a sin-damaged world. Each of us enters into a situation in which relationality has been hurt. Consequently each person is, from the very start, damaged in relationships and does not engage in them as he or she ought. Sin pursues the human being, and he or she capitulates to it. (Ratzinger 1995, IV.3)

In the German original of the teaching on original sin as "relational damage" Ratzinger questions the term "Erbsünde", which is supposed to mean a sin inherited by "biological reproduction".

By stressing the "relational" nature of "original sin" Ratzinger suggests a different form of propagation. In the Münster Lectures (1964) he considers the hypothesis that God created a first couple of human persons (man and woman) among a population of animals with human appearance, and describes it as an explanation that unifies "theological monogenism" and "biological polygenism". This distinction allowed him to argue that the notions of "monogenism" and "polygenism" do not necessarily contradict each other, since they can refer to conceptual levels that do not completely overlap („Biologischer Polygenismus und theologischer monogenismus sind deswegen nicht notwendigerweise sich ausschließende Gegensätze, weil ihre frageebene sich nicht vollständig deckt“, quoted in: Sanz 2014, 482 , Note 82 ). The transmission of sin to their descendants is then explained by "relational damage": Sin is always an offense that touches others and damages the world, so that every human being enters into a network that is marked by relational damage. However Ratzinger did not address the question of what happened to the population of non-personal but human 
looking animals: Did they disappear or rather become also transformed into persons by God?

In this context it is worth noting how Joseph Ratzinger interprets the biblical "Adam":

In the Bible this word ["Adam"] expresses the unity of the whole creature "man", so that one can speak of the biblical idea of a "corporate personality". So if Jesus is called "Adam", this implies that he is intended to gather the whole creature "Adam" in himself. (Ratzinger 2004, 236).

In the German original: „Das Neue Testament macht das erkennbar, indem es ihn einen ,Adam ' nennt; dies Wort drückt in der Bible die Einheit des ganzen Wesens Mensch aus, sodass man von der biblischen Idee einer ,Korporativepersönlichkeit' spricht.“ (Ratzinger 2005, 222).

This implies that "relational damage" could be straightforwardly extended to a primeval population of persons. A possible scenario is that at a certain moment God transformed a little or the whole population of Homo sapiens into human persons. One or more of these persons then trespassed the primeval commandment and lost the "state of original innocence". God subsequently treated those who didn't $\sin$ in the same way as those who had sinned, and all lost the state of innocence. This means: The original sin of one or more persons spread laterally to all human persons who lived at that time; the consequences of the first sin propagated in the beginning laterally from the sinners to all other existing innocent persons, and thereafter to all descendants at the very moment of their generation.

In any case Ratzinger neither reduces the propagation of original sin to "imitation of wicked progenitors", nor questions that sin damages the very essence of the human soul. However, besides the unaddressed questions referred to previously, a problem with "relational damage" may be this: Since all sins are essentially “damage of relationality”, each person's sin should add some damage to everybody (unless one assumes that the "first damage" was absolute), and therefore becomes transmitted to all other human persons in the same way as the original sin. In this sense the explanation does not seem to be very different from that of "Homo divinus" 
as proposed by Sam Berry and Graeme Finlay (this point is discussed in: Suarez 2015). It seems also to us that this scenario is somewhat at variance with God's justice: Since it was God's original wisdom to create souls sharing the gifts of the "state of innocence" (whatever they were), it would have been unjust to withdraw these gifts from someone who had not trespassed God's commandment.

\section{2."Transmission at generation"}

We propose now an alternative explanation assuming like Ratzinger that the transmission of original sin does not occur exclusively through biological heredity, but avoiding transmission of sin from sinners to non-sinners, and answering unaddressed questions:

God selected one couple among all the individuals of the species Homo sapiens and transformed them into persons in the "state of innocence". That is, He bestowed the animals with spiritual powers (intellect and free will) strong enough to perfectly master their selfish Darwinian tendencies and even overcome pain and illness. The original sin was the disobedience of these primal persons to God's commandment. God then continued to transform all the other living Homo sapiens, and from this moment bestowed each newly conceived individual with personhood. The species continued to exist in this way until the present day. However, God's plan for Redemption implied that people created after the fall could not be in the state of innocence, and so the consequences of the fall of primal human persons became transmitted to all humans at all times.

In this sense there was transmission of original sin immediately after the fall, first through transformation of already existing non-personal individuals of the species into persons, and then onward to their biological descendants. And these two types of transmission can appropriately be referred to as "transmission at generation", since in both cases it happens at the moment a new human person comes into existence.

According to this hypothesis the consequences of the first sin didn't propagate laterally to other existing innocent persons at any moment. The 
lack of righteousness emerges in all persons coming into existence after the fall at the very moment of their generation. God didn't take away his grace from persons who didn't sin, but doesn't give original grace to the persons He creates after the first sin.

A variant of this hypothesis is that God selected several couples among the living animals of Homo sapiens and transformed them into persons. Some of these first persons sinned, while God took those who kept the state of innocence away to heaven (in a similar way to the Patriarch Enoch and the Prophet Elijah). God then transformed all other Homo sapiens into persons in a "state of original sin" (peccatum originale originatum).

At first sight the option 'single couple' seems better able to fit the Genesis narrative about Adam and Eve. However, in the first three chapters of Genesis the term 'Adam' is rather used in the sense of 'humanity' (Ratzinger 2004, Berry 2011). Additionally, as far as the doctrine of original sin is concerned, there is no compulsory theological reason to exclude the possibility that the first sinners were a community. Even in the case of a single couple, it is in principle possible that generations passed before the first sin occurred (as argued in Section 2), and that it was committed by a number of people. So for the time being the question of whether the first sinners were a single couple or a community remains open. Nonetheless, the interpretation that the first sin was the deed of a primal group (consisting of more than just one couple) seems to find support in the teaching of Jesus Christ himself, and allows us to explain the content of God's primeval commandment and transgression in Genesis 3:1-6 in a natural way (Suarez 2015, Appendix 3).

\section{3. "Decree concerning original sin" of the Council of Trent}

From a Catholic perspective the Magisterium or official teaching of the Councils and the Popes is binding in matters of Faith. Therefore, it is interesting to compare the precedent conclusions to the binding declarations contained in the Decree concerning original sin of the $5^{\text {th }}$ Session of the Council of Trent, in particular the following one: 
If anyone asserts, that this sin of Adam, - which in its origin is one, and being transfused into all by propagation, not by imitation, is in each one as his own, - is taken away either by the powers of human nature, or by any other remedy than the merit of the one mediator, our Lord Jesus Christ, who hath reconciled us to God in his own blood, made unto us justice, sanctification, and redemption; [...] let him be anathema [...] (Council of Trent, 1546).

An important aspect of this declaration is that it uses the word "propagation". This clearly means that they do not limit the transfusion of the original sin to the offspring as resulting from the biological process of reproduction, but are compatible with the assumption that the original sin was also "transfused" into persons who biologically did not descend from Adam. Thereby the Trent's Decree concerning original sin does not definitely proclaim that the whole humankind originates biologically from a single couple, and in any case "Relational damage" and "Transmission at generation” totally agree to Trent's dogmatic declarations.

\section{Darwinian evolution, concupiscence, and "creation's bondage to decay"}

According to Daryl Domning there is a relationship between original sin and the Darwinian behavioural patterns responsible for evolution: The animal world is full of intra-specific aggression, deceit, theft, exploitation, infanticide and cannibalism. "Our cousins the great apes are adept at political intrigue and quite capable of serial murder and lethal warfare [...] there is virtually no known human behaviour that we call 'sin' that is not also found among nonhuman animals." Darwinian Theory teaches us "that these behaviours exist because they promote the survival and reproduction of those individuals that perform them."

The overt selfish acts that, in humans, demonstrate the reality of original sin by manifesting it as actual sin do indeed owe their universality among humans to natural descent from a common ancestor. However, this ancestor must be placed not at the origin of the human race but at the origin of life itself. Yet 
these overt acts did not acquire their sinful character until the evolution of human intelligence allowed them to be performed by morally responsible beings. We all sin because we have all inherited - from the very first living things on earth- a powerful tendency to act selfishly, no matter the cost to others. Free will enables us to override this tendency, but only sporadically and with great effort; we more readily opt for self. (Domning 2001).

A similar explanation is provided by George L. Murphy:

Our prehuman ancestors cannot be called "immoral," let alone "sinful," because they killed, deceived, were sexually promiscuous, and did other things that would be sinful for their human descendants. But when the first humans, as we have defined them, came into being, they would have had strong propensities for the same types of behavior. When they began to become aware that such actions were contrary to God's will, these creatures would have been moral agents for whom such acts were sinful. But because of their inherited tendencies, it would have been difficult for them to avoid those acts. (Murphy 2006).

The accounts by Domning and Murphy attempt to explain human concupiscence (the propensity to sin) by inherited Darwinian tendencies. In the same line of thinking Christopher Hays and Stephen Herring stress that "even if one did not believe that Adam's fall was the source of human concupiscence, one could quite easily provide an alternative account of the doctrine, saying, for example, that humans have an evolutionary biological propensity to selfishness that is reinforced and quickened by our society, psychology and spiritual estate” (Hays and Herring 2013, 53).

An alternative account could be the following: When God created the first human persons he bestowed them with intelligence and free will powerful enough to overcome the Darwinian tendencies, so that these first human beings were capable of living according to higher moral principles. This does not mean that the first humans already possessed perfect knowledge or did not need food, but rather that they would have avoided war, harming and deceiving each other, and even been able of overwhelming pain to some extent (see: Thomas Aquinas, S.th. I, q. 97 and q. 101). 
By contrast the animals continued to act according to such tendencies but, as Domning and Murphy point out, they cannot be considered to commit sins, since they are not morally responsible. The first trespass against God caused the first sinners to lose control over their powerful Darwinian tendencies, and the propensity "to act selfishly, no matter the cost to others" became transmitted as original sin. In this interpretation concupiscence is the result of both Darwinian principles and original sin.

If one assumes as a basic theological principle that God creates the human persons for the purpose that these might trust and worship Him with completely free will, then it is reasonable to claim that God created the first human persons free from concupiscence, so that they could decide to obey him without any handicap from their animality. In fact the temptation by the snake in Genesis 3:5 is a pure spiritual temptation, with the insinuation that you will "become like God", reach divine life and no longer be a creature, and this without God's help. The way the temptation progresses unveils the structure of the primeval human psyche: Eve was endowed with spiritual force to master concupiscence to the extent that it had been silly on the part of the snake to try to seduce her by praising the sensual beauty of the forbidden fruits. Instead the snake astutely challenges Eve's fidelity to God. However, as soon as Eve begins to doubt, the concupiscence emerges, and the woman by herself (without any insinuation on the part of the snake) sees that the tree is "good to eat", "a delight to the eyes", and "desirable". Gordon Wenham brilliantly comments: "The woman's covetousness is described in terminology that foreshadows the tenth commandment" (Wenham 1987, 75).

But why God does not act in the same way after the first sin and so avoid transmitting the state of original sin? The answer follows from what has been stated in the foregoing Section 3: God ardently desires to redeem fallen persons, but without violating their freedom. With this aim it is necessary to maintain only persons sharing the state of original sin and feeling concupiscence; that is, persons who are aware of the need for the Redemption and grace Jesus Christ won for us. In this respect it is significant that Jesus Christ accepts temptation by the devil, to make it clear to us that "we 
do not have a high priest who is unable to empathize with our weaknesses, but we have one who has been tempted in every way, just as we are -yet he did not sin." (Hebrews 4:15). Original sin is the product of human pride, God's respect for human freedom, and God's mercy.

Nonetheless one could still ask why God makes an animal world governed by Darwinian natural selection and full of cruelty, instead of a creation according to Isaiah's prophecy: "The wolf and the lamb will feed together, and the lion will eat straw like the ox, and dust will be the serpent's food. They will neither harm nor destroy on all my holy mountain" (Isaiah 65:25). The Darwinian cruelty of the animal kingdom, and more in general all the natural catastrophes and illness build a hostile environment that disrupts man's dominion over his body and the creatures around him (Lorda 2009, 293-294). In this sense a Darwinian world efficiently confronts man with his limits and makes him clear that he is not God (Tanzella-Nitti 2015). In other words, God may have preferred a creation subjected to frustration and bound to decay to better move humans to freely accept His Redemption and love in case they had sinned (as in fact they did). This is what St. Paul seems to express in the Letter to the Romans:

I consider that our present sufferings are not worth comparing with the glory that will be revealed in us. For the creation waits in eager expectation for the children of God to be revealed. For the creation was subjected to frustration, not by its own choice, but by the will of the one who subjected it, in hope that the creation itself will be liberated from its bondage to decay and brought into the freedom and glory of the children of God (Romans 8:18-21).

On the other hand, an evolutionary world allows us to have plenty of good things like nice meals, lovely pet animals, beautiful horses, and highly useful medical research on animal models.

An additional upshot of this discussion is that true human nature is defined by the state of original innocence, in which "the rational soul was united to the body under such a condition that in the body there can be nothing contrary to the soul by which the body lives" (Thomas Aquinas, Contra Gentiles, IV, 52, 2 and 4), and human free will was not debilitated 
by concupiscence. By contrast, the state of original sin characterises the fallen (or Darwinian) human nature, and exists in view to make redemption possible for all and restore the state of original innocence. Thus one can properly say that the original sin wounds human nature but without destroying human free will.

In conclusion: Evolution through natural selection, and more in general a creation bound to decay, seems to be a highly convenient way to bring fallen human persons "into the freedom and glory of the children of God". To this extent such an evolutionary world can even be considered the smartest form of creation on the part of God.

\section{6. 'Monogenism' and 'polygenism' are misleading and imprecise terms}

The declaration that brings the original sin in relation with the issue of "polygenism" is formulated by Pope Pius XII in his Letter Encyclical Humani generis:

When, however, there is question of another conjectural opinion, namely polygenism, the children of the Church by no means enjoy such liberty. For the faithful cannot embrace that opinion which maintains that either after Adam there existed on this earth true men who did not take their origin through natural generation from him as from the first parent of all, or that Adam represents a certain number of first parents. Now it is in no way apparent how such an opinion can be reconciled with that which the sources of revealed truth and the documents of the Teaching Authority of the Church propose with regard to original sin, which proceeds from a sin actually committed by an individual Adam and which, through generation, is passed on to all and is in everyone as his own [Cfr. Rom., V, 12-19; Conc. Trid., sess, V, can. 1-4]. (Pius XII, 1950)

A first comment regarding this declaration is that the exclusion of "polygenism" is formulated very carefully under the condition that there is no way of reconciling "such an opinion" with the Teaching of the Church regarding original sin. If this condition is not fulfilled, then doors remain open. This was stressed by Joseph Ratzinger in his Münster Lectures: "With this 
text a door is in principle quite clearly opened"; what is important for the Church is not the claim of the hominization in one couple but the claim that all human beings became guilty in their original state; "monogenism is assumed only in function of this theological statement" (Sanz 2014, 480, Notes 75 and 76). What is more, according to Ratzinger one can accept both: "biological polygenism" and "theological monogenism". (Sanz 2014, 482, Note 82).

Finally Humani generis does not define the meaning of "natural generation". It is obvious that this expression cannot mean generation through coition, since otherwise children generated in vitro would not be affected by original sin. Neither can it mean generation trough Adam's sperm cells, since this would reduce original sin to sort of genetic illness. And as we have argued in Section 1, if God had created human persons from adult animals of Homo sapiens (as we think He has done), this would have been a "natural generation", indeed as natural as that occurring when God creates human persons from zygotes today, or will create in the future from possible totipotent cells engineered by nuclear transfer or other genetic techniques, if we immorally oblige Him to do this.

In conclusion, the terms "monogenism" and "polygenism" are imprecise and not appropriate to describe what original sin is all about. In this respect the crucial statement in the quotation of Humani generis referred to above is precisely the last sentence, which unambiguously defines what the Teaching of the Church is: Original sin "proceeds from a sin actually committed by an individual Adam and which, through generation, is passed on to all and is in everyone as his own [Cfr. Rom., V, 12-19; Conc. Trid., sess, V, can. 1-4]". This is exactly what our explanation "Transmission at generation" states: Original sin passes on to all human persons at the very moment of their generation, and is in everyone as his own; Adam was the first human person who sinned, and may have been (although not necessarily) the very first human person. It is also noteworthy that Humani generis explicitly refers to the Canones $1-4,5^{\text {th }}$ Session of the Council of Trent, which use the broader formulation "by propagation, not by imitation", as we have seen in Section 4.3. 
Anyway, the text of Humani generis by Pius XII does not contradict the explanations given in Section 4 ("Relational damage" and "Transmission at generation") any more than the text of Quanta cura (December 8, 1864) by Pius IX contradicts the declaration on religious freedom as stated in the document Dignitatis humanae of the Second Vatican Council (Suarez 2013b).

As a matter of fact, the Catechism of the Catholic Church does not take account of the "polygenism" question and keeps to the term "propagation" to characterising the transmission of original sin:

By yielding to the tempter, Adam and Eve committed a personal sin, but this sin affected the human nature that they would then transmit in a fallen state. It is a sin which will be transmitted by propagation to all mankind, that is, by the transmission of a human nature deprived of original holiness and justice. and that is why original sin is called "sin" only in an analogical sense: it is a sin "contracted" and not "committed" - a state and not an act. (Catechism of the Catholic Church, Nr 404)

Interestingly, John Paul II in his Message on Evolution delivered to the Pontifical Academy of Sciences on 22 October 1996 quotes Humani generis without any reference to "polygenism":

Pius XII underlined the essential point: if the origin of the human body comes through living matter which existed previously, the spiritual soul is created directly by God ("animas enim a Deo immediate creari catholica fides non retimere iubet” [Humani Generis]). (John Paul II 1996).

The International Theological Commission, in the document "Communion and Stewardship. Human Persons Created in the Image of God" published in 2004 states:

In its original unity - of which Adam is the symbol - the human race is made in the image of the divine Trinity. While the story of human origins is complex and subject to revision, physical anthropology and molecular biology combine to make a convincing case for the origin of the human species in Africa about 
150,000 years ago in a humanoid population of common genetic lineage.[...] Catholic theology affirms that that the emergence of the first members of the human species (whether as individuals or in populations) represents an event that is not susceptible of a purely natural explanation and which can appropriately be attributed to divine intervention. (The International Theological Commission 2004).

As stated in Section 1, the assumption that the emergence of the first human persons "is not susceptible of a purely natural explanation" and requires "divine intervention" should not mistakenly be interpreted in the sense that other events in evolution happen without divine intervention. The emergence of human persons and animals are natural God-given processes, God intervenes in both although in different ways.

The question of "polygenism" was completely sidestepped in the International Conference on "Biological Evolution: Facts and theories" held on the Pontifical Gregorian University (Rome) in March 2009 (Auletta et al. 2011). By contrast a more detailed presentation of the Status questionis on "monogenism" and "polygenism" has been provided recently by Rubén Herce. Discussing the claim that "Catholic teaching requires monogenism as the only way to explain the existence of the sin in the world", he states:

Although one can invoke for it a tradition that tends to support the monogenism, one has to note that the Catholic Church has not confirmed this position by a dogmatic declaration. In fact the well-known declarations of Pius XII [in Humani generis, as quoted before] explicitly avoid a complete bond with monogenism and, by the way, they do not discuss the problem of sin on the basis of the narrative of the Genesis about man's creation, but in the Pauline statement of Jesus Christ as the new Adam.

And Herce sums up the stand of the current state of investigation in a very suggestive way:

In lack of a better explanation about the origin of the humankind and of the spiritual evil in the world, the present paradigm [monogenism] remains still valid. But even so, it is important to investigate and test whether the perceived anomalies are real, and if they necessarily lead toward a change of paradigm 
where the polygenism and a better understanding of the original sin become the key elements. It would not be wise to remain sitting on a branch that had begun to rot. (Herce 2014)

Quite interesting is also the position expressed by Fr. Funes, Director of the Specola Vaticana regarding the possibility of the existence of other living creatures and beings like us in the universe:

In my opinion this possibility does exist. Astronomers hold that the universe is formed of 100 billion galaxies, each composed of 100 billion stars. Many of these, or almost all of them, could have planets. How can we exclude that life may have developed in other places? [...] It is possible. Up to now we have no proof, but certainly in a universe so vast no hypothesis can be excluded.

And to the question of whether Redemption would be possible for extra-terrestrials if they were sinners, he answers:

Jesus became flesh only once. The Incarnation is an event which cannot be repeated. But I am sure that they, too, in some way, would have the possibility to enjoy the God's mercy just as we have had. (Funes 2008).

Pope Francis himself has recently reawakened this discussion by suggesting that one should be ready to baptize Martians if they came and asked for it (Francis 2014).

In line with Funes and Pope Francis I too think that, if one takes evolution seriously, one has to admit in principle to the possibility that other living beings like humans exist on other planets, and it is clear that they cannot have originated from a primal pair on Earth. One cannot reject this argument by claiming that "the existence of Aliens has not been proved", since unless one explicitly rejects the existence of Aliens, one has to develop an explanation of original sin and atonement in accord with this possibility for reasons of logical consistency.

In summary, the only thing that the Magisterium says Catholic faithful cannot deny in any way is the "Teaching of the Church with regard to original sin" as stated in the Council of Trent, that is, that this sin means a fallen state (peccatum originale originatum) and because of it all human 
persons require salvation, and to save us the Second Person of the Holy Trinity became a man, Jesus Christ. But the Magisterium does not state that the genetic origin of all humans from a primal couple ("monogenism") is essential for original sin and leaves open the possibility of "polygenic" origin if this is supported by science. On the other hand, as we have seen the very terms of "monogenism" and "polygenism" are ambiguous and, if one uses them, one should carefully define whether they are meant in a pure biological or rather theological sense.

Pius XII's claim regarding "polygenism" in Humani generis is formulated in such a way as to suggest that the Holy Spirit is challenging us to explore in more depth the relationship between the mystery of original sin and science, according to Anselm's fides quaerens intellectum. The final outcome of the Pope's teaching seems to be that one should not deduce original sin and Redemption from "Adam and Eve", but resort to the primeval single couple only if there is no other way of explaining how the first personal sin "is passed on to all". The arguments in this article support that other explanations are possible. According to Pope Francis, "not all discussions of doctrinal, moral or doctrinal issues need to be settled by interventions of the magisterium" (Pope Francis 2016, 3). Regarding the issue of whether or not humanity is descended from only two genetic ancestors, we think that the decision should be better left to science.

\section{The model "Transmission at generation" in the light of Genesis}

The explanation of original sin proposed in Section 4.2, and the Genesis narrative about creation of man by God, illuminate each other in various respects:

\subsection{What does the term 'living nefesh' ('living soul' or 'living creature') refer to?}

Then the Lord God formed a man from the dust of the ground and breathed into his nostrils the breath of life, and the man became a living creature. (Genesis 2:7). 
The same term 'living nefesh' ('living creature') in the immediate context of Genesis refers clearly and repeatedly to non-human animals: these and Adam are made from the dust of the ground, and are each a 'living nefesh' (Stone 2004, 54-56). “It is not man's possession of 'the breath of life' or his status as a 'living creature' that differentiates him from the animals" (Wenham 1987, 60-61). Thus Genesis 2:7 can be read in correspondence to the gradual evolution of Homo sapiens in Africa about 150,000 years ago consisting of non-personal human animals.

\subsection{Mankind's original vocation: To be in "the image of God" through family and work}

So the Lord God caused the man to fall into a deep sleep; and while he was sleeping, he took one of the man's ribs and then closed up the place with flesh. Then the Lord God made a woman from the rib he had taken out of the man, and he brought her to the man. (Genesis 2:21-22).

Personhood as a result of divine intervention is suggested in Genesis 2:22 by the fact that God creates the man and the wife as called to fulfil their existence in relation to each other, that is, in the context of an interpersonal ontology (Ratzinger 1995, 72-73; Alexander 2008, 197). Thus the "deep sleep" referred to in Genesis 2:21 can be considered to correspond to the creation of primeval human persons from the modern humans.

The creation of mankind as "male and female" appears in Genesis 1:26-27 immediately after the declaration "in the image of God he created them":

Then God said, "Let us make mankind in our image, in our likeness, so that they may rule over the fish in the sea and the birds in the sky, over the livestock and all the wild animals, and over all the creatures that move along the ground."

So God created mankind in his own image, in the image of God he created them; male and female he created them.

Pope John Paul II puts this text in relation to God's Trinitarian Life:

It is, rather, the original plan of the Creator who from the "beginning" willed the human being to be a "unity of the two", and willed man and woman to be 
the prime community of persons, source of every other community, and, at the same time, to be a "sign" of that interpersonal communion of love which constitutes the mystical, intimate life of God, One in Three. (John Paul II 1998, 52).

Confirming this teaching Pope Francis states:

Seen this way, the couple's fruitful relationship becomes an image for understanding and describing the mystery of God himself, for in the Christian vision of the Trinity, God is contemplated as Father, Son and Spirit of love. The triune God is a communion of love, and the family is its living reflection. (Pope Francis 2016, 10-11).

Similarly, Karl Barth assumes that the intradivine I-Thou relationship of the triune God is reflected in the human relationship between the I and the Thou, between male and female. J. Richard Middleton's questions this interpretation of Genesis 1:27 as misguided, mainly because 'male' and 'female' "are biological, not social, terms and thus cannot support either the notion of human relationality or culturally male/female characteristics." By contrast, the creation story of Genesis 2 uses the social categories of "man" and "woman, wife". (Middleton 2005, 22-23, 49-50).

Undoubtedly, the intra-divine relationship of the triune God is rather an element of the New Testament. However, in reply to Middleton one could claim that in this case it may be appropriate to apply the principle that "Novum in Vetere latet". Indeed it is Jesus Christ himself who teaching about divorce (Matthew 19:3-9 and Mark 10:1-12), refers explicitly to Genesis 1:27, explains this verse using Genesis $2: 24$, and clearly interprets the male-female relationship as a unity of two persons who God himself joins in one flesh. In any case, Genesis 2:22-24 describes human existence as an "interpersonal communion of love", and Jesus Christ reveals to us that this is also an appropriate way for describing God's life.

On his part, Middleton focuses on Genesis 1: 26 and proposes the interpretation that Genesis 1 depicts creation as an "act of loving power" and "the model for human action". God is "a generous creator" inviting humanity to participate in the unfinished creative (and historical) process" and 
so become "the imago Dei" (Middleton 2005, 296-297). Gordon Wenham shares a similar view: "mankind is here commissioned to rule nature as a benevolent king, acting as God's representative over them [the animals] and therefore treating them in the same way as God who created them." (Wenham 1987, 33). In my opinion Middleton's and Wenham's views are not opposed to Barth's "relational" interpretation, but rather complement it, and both should be seen in connection to Genesis 2:15. To state that human "ruling over the world" ought to be an act of creative love ultimately makes work a gift that God bestows on mankind (Wenham 1987, 67) in order to care for the world and develop personhood, that is, the relationship with God and other persons.

We find this very interpretation also in the teaching of the last Popes John Paul II, Benedict XVI and Francis:

The Church finds in the very first pages of the Book of Genesis the source of her conviction that work is a fundamental dimension of human existence on earth. An analysis of these texts makes us aware that they express - sometimes in an archaic way ... - the fundamental truths about man, in the context of the mystery of creation itself. These truths are decisive for man from the very beginning, and at the same time they trace out the main lines of his earthly existence, both in the state of original justice and also after the breaking, caused by sin, of the Creator's original covenant with creation in man. [...] Man is the image of God partly through the mandate received from his Creator to subdue, to dominate, the earth. In carrying out this mandate, man, every human being, reflects the very action of the Creator of the universe. (John Paul II 1981, 4. In the same sense: Benedict XVI 2008; Francis 2016, 23).

If interpersonal relationship and creative loving work make man in "the image of God", then sin impairs this relational capacity (mainly between man and woman), and the unity of human ability and the worship of God. In the same line of thinking one may interpret "eternal death" (eradication of "the image of God") as forever becoming an individual who is intrinsically incapable of communication, who can neither call others nor be called by others, an individual without a name. 
In summary, the biblical expressions of creating mankind "in the image of God", creating them "male and female", and putting them in the world "to work it and take care of it", together define mankind's personal appearance and vocation, and can be consistently interpreted as happening later in time than the appearance of the human 'living nefesh'.

\subsection{The "sons of God" in Genesis 6}

And it came to pass, when men began to multiply on the face of the earth, and daughters were born unto them, that the sons of God saw the daughters of men that they were fair; and they took them wives of all which they chose. (Genesis 6:1-2)

These "sons of God" are undoubtedly human persons, since they are supposed to have generated children with the "daughters of men", who were persons resulting from the procreation of humankind.

Hence, these Genesis verses seem to speak about two kinds of human persons with different origin:

- Human persons originating genetically from other human persons through the union between a father (male person) and a mother (female person). The "daughters of men" Genesis 6 refers to were such persons, the same way as Cain, Abel and Seth were. Actually, all these persons are created by God at the moment of conception after coition.

- Human persons which did not originate through a conception event in the follow of intercourse between father and mother, but were created from God at the occasion of another event. This was the case of Adam and Eve themselves, according to the biblical narrative. And the "sons of God" Genesis 6 refers to can be considered persons belonging to this type as well, that is, human persons born not of human decision to procreate or a "husband's will”, but born of God.

According to our explanation "Transmission at generation" most of the persons of type 2 were generated after the fall (the first sin), and thus came into existence in the state of original sin (without original innocence). 
Therefore these "children of God" were not "holier" than the persons generated through conception after the fall (as the Genesis narrative confirms). However, since they came into existence exclusively on God's decision and without any procreation act on the part of human parents, they can appropriately be considered "children of God" in a stronger sense than the human persons coming into existence through conception. On the other hand they are the result of Adam's sin, and in this sense they can be said to originate from Adam although not genetically. Pope Francis introduces a very profound characterization of human generation when he states that a child shares "not only genetically but also spiritually in the 'flesh' of both parents" (Francis 2016, 13). Similarly the human persons generated after the first sin can be considered to share spiritually in the "flesh" of the first sinners "Adam and Eve", even if they are not genetically descended from them. God made all the nations from one man, the "first sinner", to dwell on the entire surface of the earth (Acts 17:26): We are really conceived through and in Adam's sin.

\subsection{The universal priesthood of the primeval persons and Melchizedek}

Here we want to complete "Transmission at generation" with a natural speculation following the theological approach that John Paul II developed in the audiences at the beginning of his Pontificate (1979-1982). The key tenet of this method is that for better understanding the state of humanity after the fall and Redemption, it can be useful to reflect about the way things were in the state of original righteousness.

Genesis tells us that "Adam and Eve" received mission from God to be fruitful and increase the number of human beings on Earth. In the state of original innocence Humanity was identical with the "People of God". And generating new persons in the state of righteousness was much more than a mere demographic goal: It was the mission of increasing the People of God as central implication of the vocation to unfold God's image.

One way the primeval persons were supposed to realise this mission was obviously by generating children through "becoming one flesh". This 
interpretation receives support from John Paul II, who very appropriately refers to marriage as "primordial sacrament" (John Paul II 1982).

But nothing speaks against assuming that God committed "Adam and Eve" also to collaborate with Him for transforming existing human animals into human persons, likely through some ritual of laying on of hands and giving a name. Between the "ritual of coition" and that of say "laying on of hands" there is no substantial difference: In both cases it is God who creates a soul when human persons fulfil an act that God has established as necessary for generating a new person.

To the extent that this is true, "Adam and Eve" were called:

- To become the ancestors from whom all humans originate spiritually as persons (although not all genealogically or through genetically ancestry).

- To be priests serving to build up the People of God: In the state of innocence everyone would have shared a unique common existential priesthood, "a royal priesthood" (1 Peter 2:9).

According to the latter mission "Adam and Eve" may have transformed other individuals of the species Homo sapiens into persons in the state of original grace (before the arrival of the fall). And these persons can be said to be without genealogy, although originating spiritually from Adam's priesthood.

After the fall the primeval human persons lost their priestly power to generate children of God (people in state of original grace). Humanity entered the stage of "good and bad": God Himself transformed all other human animals into persons in "state of original sin" (the God's sons of Genesis 6), and engraved on their hearts the principle of Law (the "Golden Rule") to protect them from each other. To some extent the history of Revelation can be described as God's effort to convince human persons that it is worth living according to the principle founding law and rights. And since the first sin, any sin is ultimately reduced to a trespass against this principle. The first sin, and any subsequent sin, breaks the solidarity of humanity, and the Redemption by Jesus Christ is a work to restore the lost unity (O’Callaghan 2014). 
In agreement with John Paul II's approach it is reasonable to assume (as stated in Section 4.2) that among this primeval population some kept the state of original righteousness and common priesthood, and were translated into heaven in a way similar to the Patriarch Enoch and the Prophet Elijah who were translated by God, according to the Biblical narrative.

One could then even speculate that the High Priest Melchizedek (Genesis 14:18-20) "having neither genealogy nor end of life" (Hebrews 7), may have been one of those primeval righteous persons and "royal priests" who were translated into heaven: He then came again as "Righteous King" and "Priest of God Most High" to found the Order according to which Jesus Christ "is Priest for ever".

\section{Conclusion}

The hypothesis that "humanity could not have had only two genetic ancestors at any time in the last several hundred thousand years" does not conflict at all with the Catholic teaching about the creation of the first human persons and original sin.

Anthropologically it is fitting to assume that God created the first human persons by replacing the animal souls of adult Homo sapiens individuals through human spiritual souls. This creation could have happened at the time when Homo sapiens already had a large population size, and involved basically two steps: First God created a couple or a little community of persons, who at some moment did transgress a primeval divine commandment. Then God transformed into persons all the existing human animals.

The analysis in this article shows that the propagation of original sin in this historical context can be explained through "Transmission at generation": According to Romans 11:32 it is not suitable for the sake of Redemption that people who need Redemption coexist with people who doesn't need it; therefore after the first sin only people in need of Redemption can dwell on earth and, to ensure this, God creates any new person in the state of original sin; this happens as well for human persons God creates 
by replacing the animal soul of an adult Homo sapiens individual through a human spiritual soul, as for those He creates in concomitance with fertilization after coition.

The main implications of "Transmission at generation" are: 1) Original $\sin$ is a state which proceeds from the first sin, and is "transmitted by propagation and not by imitation" to all human persons since the first trespass, so that "the state of original sin is in everyone as his own" (Council of Trent 1546). 2) The biblical "Adam" is identical to the first human person who sinned, but is not necessarily identical to the first human person who ever existed. 3) Although caused by human persons, original sin can be considered a state that makes it possible for mankind to be redeemed by God, and in this sense is also the work of divine mercy. 4) The state of original sin is provoked through the very first sin, which is the personal misdeed of one person, even if it is subsequently committed by several persons (couple or community) acting as "if they were but one person". 5) "Transmission at generation" suggests novel interpretations that may clarify Genesis tales considered mysterious till now. 6) "Monogenism" and "polygenism" are ambiguous terms that do not contribute to a precise description of the origins of personal humanity.

In conclusion: Christian faith does not require that the first $\sin$ (which induced the state of original $\sin$ ) was the misdeed of a single couple of persons, man and woman, from whom all mankind is genetically descended. Original sin could have happened at the dawn of civilisation, when Homo sapiens already exhibited a large population size.

\section{References}

(All web sites have been accessed on April 21, 2016)

Adams, Peter and Suarez, Antoine. 2013. "Exploring Free Will and Consciousness in the Light of Quantum Physics and Neuroscience." In Is Science compatible with Free Will?, edited by Antoine Suarez and Peter Adams, 273-290. New York: Springer. 
Alexander, Denis. 2008. Creation or Evolution. Do we have to choose? Oxford, UK: Monarch Books.

Augustine of Hippo. 412. On Merit and the Forgiveness of Sins, and the Baptism of Infants (Book I, IX-X). http://www.newadvent.org/fathers/15011.htm

Auletta, Gennaro, Marc Leclerc, and Rafael A. Martínez (eds.). 2011. Biological Evolution: Facts and theories. A Critical Appraisal 150 Years After "The Origin of Species”. Roma: Gregorian Biblical Press.

(Pope) Benedict XVI. 2008. Address at Collège des Bernardins, Paris, Friday, September 12 .

(Pope Emeritus) Benedict XVI. 2016. “Interview.” L’Osservatore Romano, March 17. http://www.catholicnewsagency.com/news/full-text-of-benedict-xvis-recentrare-and-lengthy-interview-26142/

Berry, James R. 2011. “Adam or Adamah?” Science \& Christian Belief 23: 23-48.

Burkhart, Ernst. 2015. Gott Rechnet mit Dir. Wien: Fassbaender.

Caballero, Juan Luis. 2014. "Rm 5,12 y el pecado original en la exégesis católica reciente.” Scripta Theologica 46 (1): 121-140.

Clark, Malcolin W. 1969. "A legal Background to the Yahwist's Use of 'Good' and 'Evil' in Gen 2-3.” Journal of Biblical Literature 88: 266-278. (Quoted in Gordon J. Wenham, Word Biblical Commentary I, Genesis 1-15, Word books: Waco Texas, 1987, p. 64).

Catechism of the Catholic Church. 1997. Nr 404. http://www.vatican.va/archive/ENG0015/_P1C.HTM

(The) Council of Trent. 1547. $5^{\text {th }}$ Session, Decree concerning Original Sin (June 17).

Coyne, Jerry A. 2014. “Ken Miller gets big Catholic prize”, whyevolutionistrue-blog, April 15. https://whyevolutionistrue.wordpress.com/2014/04/15/ken-millergets-big-catholic-prize/ (see also: Faith vs. Fact. 2015. New York: Viking Penguin, Chapter 1 and 3).

Darwin, Charles. 1859. On the Origin of Species.

Dawkins, Richard. 2012a. "Richard Dawkins Explains Why There Was Never a First Human Being." Open Culture. June 19. http://www.openculture.com/2012/06/richard_dawkins_explains_why_there_was_never_a_first_human_being.html

Dawkins, Richard. 2012b. "George Pell vs. Richard Dawkins.” Debate ABC-TV, 9 April. http://www.abc.net.au/tv/qanda/txt/s3469101.htm

Domning, Daryl P. 2001. “Evolution, Evil and Original Sin.” America November 12. http://americamagazine.org/issue/350/article/evolution-evil-and-original-sin

Driessen, Alfred. 2015. “What about Adam and Eve?” SlideShare July 2. http://www. slideshare.net/ADriessen/what-about-adam-and-eve 
Fogassi, Leonardo, and Rizzolatti, Giacomo. 2013. "The Mirror Mechanism as Neurophysiological Basis for Action and Intention Understanding.” In Is Science compatible with Free Will?, edited by Antoine Suarez and Peter Adams, 117-134. New York: Springer.

(Pope) Francis. 2016. Amoris laetitia. https://w2.vatican.va/content/dam/francesco/ pdf/apost_exhortations/documents/papa-francesco_esortazione-ap_20160319_ amoris-laetitia_en.pdf

(Pope) Francis. 2014. Quoted in Time, May 13. http://time.com/97695/pope-francis-would-baptize-martians/

Funes, José Gabriel. 2008. “Interview.” L'Osservatore Romano, Weekly Edition in English, 11 June. http://www.ewtn.com/library/ANSWERS/intfrfunes.htm

Green, Joel B. 2004. "Resurrection of the body." In Joel B. Green, What about the Soul? Neuroscience and Christian Anthropology. Nashville: Abingdon Press.

Hays, Christopher M., and Herring, Stephen Lane. 2013. "Adam and the fall.” In Evangelical Faith and the Challenge of Historical Criticism, edited by Christopher M. Hays and Christopher B. Ansberry, 24. Grand Rapids: Baker Academic.

Herce, Rubén. 2014. “Monogenismo y poligenismo. Status Quaestionis.” Scripta Theologica 46 (1): 105-120.

(The) International Theological Commission. 2004. Communion and Stewardship. Human Persons Created in the Image of God, No 43, 63 and 70. http://www. vatican.va/roman_curia/congregations/cfaith/cti_documents/rc_con_cfaith_ doc_20040723_communion-stewardship_en.html

(Pope) John Paul II. 1998. Christifideles laici.

(Pope) John Paul II. 1996. Message on Evolution, delivered to the Pontifical Academy of Sciences, 22 October.

(Pope) John Paul II. 1982. Audience October 13.

(Pope) John Paul II. 1981. Laborem exercens.

Li, Heng, and Durbin, Richard. 2011. "Inference of human population history from individual whole-genome sequences.” Nature 475: 493-496.

Lorda, Juan Luis. 2015. “La evolución, entre ciencia, razón y fe.” Scientia et Fides 3 (1): 163-183. DOI: http://dx.doi.org/10.12775/SetF.2015.007.

Lorda, Juan Luis. 2009. Antropología Teológica. Barañáin (Navarra): Eunsa.

Lewis, Clive Staples. 1940. The problem of pain, Chapter VI: Human pain.

McEvedy, Colin and Jones, Richard. 1978. Atlas of World Population History, 342-351. New York. Quoted in: United States Census Bureau: World Population. Historical Estimates of World Population. Lower estimate. http://www.census.gov/ population/international/data/worldpop/table_history.php 
Middleton, J. Richard. 2005. The Liberating Image, Brazos Press: Grand Rapids 2005. Murphy, George L. 2006. "Roads to Paradise and Perdition: Christ, Evolution, and Original Sin.” Perspectives on Science and Christian Faith 58 (2), June: 109-118. O’Callaghan, Paul. 2014. "Una lectura cristológica de la doctrina del pecado original.” Scripta Theologica 46 (1): 161-180.

(Pope) Pius XII. 1950. Humani generis, sec. 37.

Qiaomei Fu et al. 2014. "Genome sequence of a 45,000-year-old modern human from western Siberia." Nature 514: 445-450.

Ratzinger, Joseph/Benedikt XVI. 2014. Im Anfang schuf Gott. Vier Predigten über Schöpfung und Fall. Einsiedeln, Freiburg i. Brsg.: Johannes Verlag.

Ratzinger Joseph. 2005. Einführung in das Christentum. München: Kösel 6. Auflage. Ratzinger Joseph. 2004. Introduction to Christianity. San Francisco: Ignatius Press. Ratzinger Joseph. 1995. "In the Beginning...”: A Catholic Understanding of the Story of Creation and the Fall. Grand Rapids: Eerdmans.

Ratzinger, Joseph. 1986. Im Anfang schuf Gott. Vier Predigten über Schöpfung und Fall, München: Institut Papst Benedikt: Erbsünde; http://www.institut-papst-benedikt.de/nc/ergebnisausgabe/schriften/erbsuende/text/erbsuende.html

Sanz Sánchez, Santiago. 2014. “Joseph Ratzinger y la doctrina de la creación: los apuntes de Münster de 1964 (y III). Algunos temas debatidos.” Revista Española de Teología 74: 453-496.

Scally, Aylwyn, and Durbin, Richard. 2012. "Revising the human mutation rate: implications for understanding human evolution." Nature Reviews Genetics 13: $745-753$.

Stone, Lawson G. 2004. “The Soul: Possession, Part, or Person?” In What about the Soul?, edited by Joel B. Green. Nashville: Abingdon Press.

Suarez, Antoine . 2015. "Can we give up the origin of humanity from a primal couple without giving up the teaching of original sin and atonement?” Science \& Christian Belief 27: 59-83, and Appendices 1-4. https://www.scienceandchristianbelief.org/view_abstract.php?ID=1259

Suarez, Antoine. 2013a. "Free Will and Nonlocality at Detection as Basic Principles of Quantum Physics.” In Is Science compatible with Free Will? Exploring Free Will and Consciousness in the Light of Quantum Physics and Neuroscience, edited by Antoine Suarez, and Peter Adams, 63-79. New York: Springer.

Suarez, Antoine. 2013b. “The Social Question Is Radically an Anthropological Question: The Perspective of Caritas in Veritate." Journal of Markets\&Morality 16 (1): 85-99. Suarez, Antoine. 2011. "Is this Cell Entity a Human Being? Neural Activity, Spiritual Soul, and the Status of the Inner Cell Mass and Pluripotent Stem Cells." In Is this cell a human being?, edited by Antoine Suarez and J. Huarte, 171-192. Heidelberg: Springer. 
Suarez, Antoine and Huarte, Joachim. 2011. Is this cell a human being? Heidelberg: Springer.

Tanzella-Nitti, Giuseppe. 2015. Questioni teologiche scelte sul peccato originale, Chapter: V. Temi di attualità legati al confronto con la storia e con le scienze, Roma; Teologia della credibilità in contesto scientifico II, capitoli XI e XII, Città Nuova: Roma 2015. http://www.tanzella-nitti.it/sites/default/files/media/ pdf/2015_Lezioni-Peccato-originale_0.pdf

Thomas Aquinas. Summa theologica (S.th.),

- I, q. 76, a. 3, Reply to Objection 3. http://www.newadvent.org/summa/1076. htm\#article3

- I, q. 97 http://www.newadvent.org/summa/1097.htm

- I, q. 98, a. 1 http://www.newadvent.org/summa/1098.htm

- I, q. 100, a. 1 and a. 2 http://www.newadvent.org/summa/1100.htm

- I, q. 101 http://www.newadvent.org/summa/1101.htm

- I, q. 118, a. 2, Reply to Objection 2. http://www.newadvent.org/summa/1118. htm\#article2

- I-IIae, q. 79, a. 2 http://www.newadvent.org/summa/2079.htm\#article2

- I-IIae, q. 81, a. 3 http://www.newadvent.org/summa/2081.htm\#article3c

- I-IIae, q. 81, a. 4, On the contrary http://www.newadvent.org/summa/2081. htm\#article 4

- I-IIae, q. 81, a. 5 http://www.newadvent.org/summa/2081.htm\#article5

- I-IIae, q. 83, a. 1, Reply to Objection 4. http://www.newadvent.org/sum$\mathrm{ma} / 2083$. htm\#article1

- I-IIae, q. 83, a. 2 http://www.newadvent.org/summa/2083.htm\#article2

Thomas Aquinas. Summa contra gentiles, IV, 52, 2 and 4 http://dhspriory.org/thomas/ContraGentiles4.htm\#52

Wenham, Gordon J. 1987. Word Biblical Commentary I, Genesis 1-15. Waco Texas: Word books. 